\title{
ANALISIS TEGANGAN INSERT CAVITY MOLDING RAK SEPATU TERHADAP TEKANAN 160 MPA PADA MESIN INJECTION PLASTIK MENGGUNAKAN SOFTWARE AUTODESK INVENTOR PROFESSIONAL 2017
}

\author{
Mohammad Ihya' Ulumuddin \\ Teknik Mesin, Fakultas Teknik \\ Universitas Maarif Hasyim Latif, Sidoarjo, Indonesia \\ e-mail : mohammad-ihya-ulumuddin@student.umaha.ac.id
}

\begin{abstract}
ABSTRAK
Plastik merupakan salah satu bahan baku untuk membuat suatu product plastik yang berguna untuk memenuhi kebutuhan manusia, Selama pengamatan di PT X terutama dalam proses pembuatan desain molding, di tempat tersebut tidak melakukan analisis desain menggunakan software, oleh sebab itu penulis membuat analisis molding menggunakan software, penelitian ini bertujuan menganalisis kekuatan plate insert cavity pada saat mendapatkan tekanan $160 \mathrm{MPa}$ dari mesin injection untuk mengetahui tegangannya perlu dilakukan analisis memakai software autodesk inventor profesioanl 2017 Pada analisis ini dilakukan studi langsung di PT X Proses analisis diawali dengan membuat desain 3D molding kemudian masuk ke menu stress analysis pada kotak dialog pressure dimasukan data tekanan yang sebesar $160 \mathrm{Mpa}$, untuk bahan molding yang digunakan untuk analisis adalah stainless steel, setelah data masuk semua bisa langsung dijalankan simulation tegangannya, dari analisis akan diperoleh data tegangan seperti von misess, stress, strain, displacment, .dan safety factor Berdasarkan hasil analisis statis didapat kekuatan molding yaitu nilai von mises stress maksimum adalah 124,2 Mpa, nilai Stress maksimum adalah 118,1 Mpa, nilai displacement maksimum adalah $0,06579 \mathrm{~mm}$, nilai strain maksimum adalah $6,03 \times 10^{-4}$, dengan nilai faktor keamanan 2,01 maka faktor kemanan beban pada molding masih aman mengunakan bahan stainless steel.
\end{abstract}

Kata kunci: Autodesk Inventor Profesional 2017, Molding, Plastik, Stress Analysis, Simulation, Stainless Steel

\section{PENDAHULUAN}

Di dalam industri sekarang ini khususnya pada bidang pembuatan produk berbahan plastik sangat berkembang dimana-mana baik dari segi desain produk maupun kegunaannya yang semakin beragam, dalam segi desain sekarang ini sudah banyak sekali perusahaan yang menyediakan bermacam-macam software desain seperti : Autodesk Inventor professional, Solidwork, Pro-e dan lain-lain software tersebut memiliki keunggulannya masing-masing, salah satu keunggulan dari software desain yaitu menganalisis beban pada gambar 3D, sedangkan PT X perusahaan plastik masih belum melakukan analisis pada desain-desainnya yang sebenarnya sangat penting melakukan analisis desain pada produk diperusahaan tersebut karena bisa meningkatkan qualitas molding maupun produknya nanti, yang dilakukan saat ini diperusahaan tersebut hanya mengacu katalog, dengan proses begitu ketika mendapatkan desain yang tidak ada di katalog mereka mengalami kesulitan dalam menentukan dimension dengan akurat cenderung dilakukan over material

Dalam kemajuan menganalisi sebuah desain penulis berharap untuk para desiner melakukan analisis desain menggunakan software terlebih dahulu , dengan menganalisis desain menggunakan software kita dapat mengetahui titik tidak aman suatu desain ketika terkena beban sehingga dapat segera di atasi sebelum barang dibuat

Hal ini yang mendorong penulis untuk melakukan sebuah analisis molding yang berada di PT X dengan harapan perusahaan tersebut bisa mengikuti berkembangan teknologi terbaru dan dapat bersaing dengan kompotitor, sebenarnya banyak sekali proveder yang menyediakan software desain tetapi hanya beberapa yang dapat digunakan untuk menganlisisi seperti : Autodesk Inventor Professioanl, solidwork, Pro-e, dan lainlain, kali ini penulis menganalisa menggunakan software autodesk inventor professional 2017.

\section{METODE PENELITIAN}

Perancangan desain molding merupakan proses awal kegiatan dari usaha menghasilkan suatu produk yang dibutuhkan masyarkat untuk memenuhi kebutuhan hidup. Setelah perancangan molding selesai kegiatan selanjutnya adalah menganalisa molding untuk menghasilkan produk yang sesuai dengan direncanakan. Kegiatan merancang molding dilakukan oleh desain mold 
dan kegiatan pembuatan produk dilakukan oleh orang produksi.

Sebelum melakukan perancangan desain molding itu sendiri harus melalui beberapa serangkaian kegiatan yang berurutan yaitu membuat analisa produk kompotitor yang lagi diminati masayarakat saat ini, kemudian mendiskusikan dengan team untuk membuat pengembangan produk dari kompotitor yang ada di pasaran setelah diperoleh hasil diskusi, maka akan dilanjutkan dengan membuat rancangan desain produk terlebih dahulu kemudian dilanjut pembuat rancangan molding dari produk tersebut, Setelah desain produk dan molding sudah selesai didesain maka akan dilakukan analisa menggunakan software yang mendukung dilakukanya analisa. Maka dari itu perancangan disebut sebagai poses perancangan yang menentukan proses selanjutnya sampai selesai. Kegiatan - kegiatan atau fase - fase dalam proses perancangan berbeda satu dengan yang lain. Berikut fase - fase dalam sebuah proses perancangan desain molding :

1. Studi Observasi

2. Studi literature

3. Pengambilan data mesin

4. Pembuatan Desain

5. Metode Analisis

6. Von Misess

7. Stress

8. Displacment

9. Strain

10. Safety Factor

11. Report Analisis Molding

12. Pembuatan Laporan

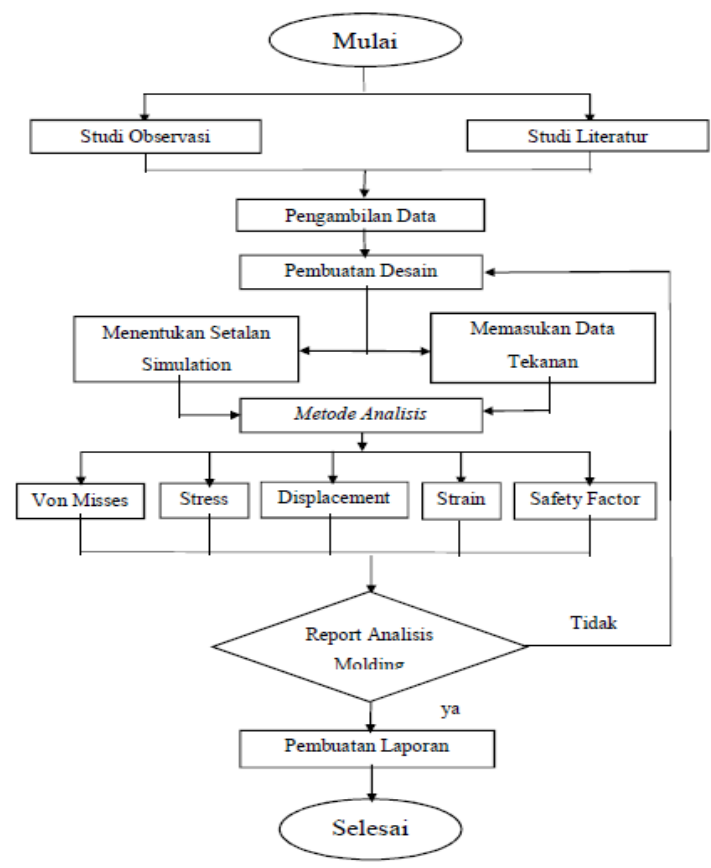

Gambar 1 Flowchart
Dalam pelaksanaan pembuatan tugas akhir ini melalui beberapa prosedur pengujian sebagai berikut :

\section{Studi Observasi}

Setelah mengamati pekerjaan molding di salah satu bengkel yang berada di daerah Waru Sidoarjo ada beberapa prosedur yang menurut penulis masih belum dilakukan yaitu analisa molding menggunakan software desain, Karena selama ini hasil pengamatan penulis pekerjan yang dilakukan di bengkel tersebut khususnya bagian perancangan desain hanya mengandalkan pengalaman dari trail end error yang terdahulu dan mengacu pada katalog molding saja, yang seharusnya ditambah lagi dengan analisa desain menggunakan software yang semakin canggih seiring berkembangnya perindustrian saat ini.

\section{Studi Literatur}

Perencanaan analisis desain molding ini berdasarkan literatur yang mempunyai relevansi dengan permasalahan yang akan dihadapi, baik buku teks, jurnal, penelitian dan lain-lain, hal ini dimaksudkan untuk memperoleh data teknik maupun data tesis mengenai segala hal yang berhubungan dengan analisis menggunakan software autodesk inventor.

\section{Pengambilan Data}

Data yang diperlukan untuk membuat molding dan kemudian di analisis yaitu mencari molding yang sudah tidak terpakai lagi tetapi masih bisa di manfaatkan bagian-bagian komponennya, kemudian mencari data spesifikasi mesin injection plastic yang akan digunakan pada saat menginput data ke software autodesk inventor supaya bisa dibuat analisis.

\section{Pembuatan Desain}

Setelah data telah siap maka dilakukan perancang desain menggunakan software autodesk inventor. Pertama yang harus dilakukan sebelum menganalisa desain molding yaitu dengan membuat desain produk terlebih dahulu sebagai emboss moldingnya, setelah selesai membuat desain produknya dan sudah dipersetujui oleh beberapa pihak yang terkait, baru proses pembuatan desain molding bisa dilakukan dengan mempertimbangkan bentuk produknya , dari desain produk dan desain molding yang sudah jadi maka bisa langsung di buat analisisnya menggunakan software autodesk inventor.

\section{Menentukan Setelan Analysis}

Untuk menetukan jenis analisis yang akan dipakai untuk kali ini penulis mengunakan jenis analisis static, menentukan material yang digunakan, menentukan point penempatan tekanan.

\section{Memasukan Data Tekanan}

Setelah data tekanan mesin diperoleh dari mesin injection yang berupa nilai tekanan, nilai 
tersebut dimasukan kedalam load pressure yang berada di toolbar Stress Analysis inventor, kemudian di klik pada point yang sudah ditentukan.

\section{Metode Analisis}

Untuk kali ini metode yang digunakan menggunakan simulation stress analysis yang ada pada autodesk inventor 2017, Metode analisis suatu pengolahan desain yang bisa menghasilkan suatu nilai kekuatan suatu desain, kali ini desain molding rak sepatu yang akan di analisa sehingga menghasilakan data von mises, Stress, Strain, Dispalcemet, dan Safety Factor.

\section{Teori Energi Distorsi (Von Mises)}

Setelah software selesai menganalisi maka akan muncul hasil seperti von misess, kemudian nilai von mises molding yang keluar di analisis apakah hasil yang didapat melebihi tegangan luluh dari material, dari analisis ini dapat disimulasi untuk mengetahui berbedanya dengan melihat perubahan warna pada part yang sudah di analisis

\section{Tegangan (Stress)}

Tegangan adalah reaksi yang timbul diseluruh bagian plate insert molding dalam menahan beban yang diberikan. Satuan gaya yang digunakan dalam penjabaran tegangan adalah satuan gaya dibagi dengan satuan luas. Pada satuan SI, gaya diukur dalam Newton (N) dan luas diukur dengan satuan Meter Kuadrat (m2). Biasanya 1 N/m2 dikenal sebagai 1 Pascal (Pa). dari reaksi yang timbul bisa di analisis berapa saja tekanan yg terjadi di setiap sudut partnya baik yang terkena tekanan langsung maupun yang tidak langsung, dengan melihat perubahan warna angka yang ditampalikan setelah setelah selesai dianalisi

\section{Lendutan ( Displacement )}

Untuk hasil displacement menunjukan perubahan bentuk dari desain setelah dilakukan pembebanan, di analaisi tegangan ini untuk mengetahui perubahannya dengan cara melihat perubahan warna pada molding yang disertai hasil angka, displacement kali ini untuk mengetahui material molding masih berada pada daerah elastis, jika nilai displacement cukup kecil maka masih dapat diterima.

\section{Regangan (Strain)}

Strain atau tarik adalah hasil bagi antara pertambahan panjang $(\Delta \mathrm{L})$ dengan panjang awalnya (L). Regangan atau tarik dinotasikan dengan (e) dan regangan tidak memiliki satuan atau dimensi karena pertambahan panjang $\Delta \mathrm{L}$ dan $\mathrm{L}$ adalah sama. Unuk mengetahui bahan molding mengalami pertambahan panjang dari ukuran yang sebelumnya dengan cara melihat perubahan warna ketika simulasi dilakukan.

\section{Faktor Keamanan (Safety Factor)}

Safety factor atau angka keamanan merupakan salah satu parameter penting untuk menentukan apakah suatu konstruksi itu aman atau tidak. Safety Factor merupakan perbandingan antara tegangan ijin bahan dengan tegangan yang terjadi. Konstruksi dinyatakan aman apabila angka keamanannya di atas satu.

\section{Report Analisis Molding}

Mengumpulkan semua hasil dari Analisis yang sudah disimulasikan dari software autodesk yang berupa file HTML, di file tersebut terdapat spesifikasi Physical, Material, dan Pressure yang ada pada desain molding, untuk hasil analisis terdapat Stress, Strain, Von Mises, Displactment, Saftey Factor, hasilnya akan keluar jika proses analisisnya berhasil kalau tidak keluar atau gagal maka ada beberapa factor yang membuat gagal yaitu desain prodak, desain molding atau pada prosedur menganalisanya.

\section{Penulisan Laporan}

Pembuatan laporan merupakan tahap akhir dalam melakukan penelitian kali ini, setelah melalui beberapa uji coba yang panjang akhirnya bisa menyelesaikan penyusunan penelitian.

\section{Bahan dan Alat}

Maka dari itu yang pertama kali disiapkan untuk membuat analisis desain molding yaitu :

\section{Bahan}

a. Installer autodesk inventor 2017

\section{Alat - Alat :}
a. Laptop atau pc 1 set
b. Skatmat
c. Meteran
d. Kertas HVS
e. Bulpoin

\section{Tempat dan Waktu Penelitian}

Adapun waktu dan tempat dilakukan proses analisis molding rak sepatu yang di jelaskan langkah - langkahnya sebagai berikut :

Tabel 1 Tempat dan waktu penelitian

\begin{tabular}{|c|l|l|l|l|}
\hline No & $\begin{array}{c}\text { Hari/ } \\
\text { Tangga } \\
\text { l }\end{array}$ & Jam & Tempat & $\begin{array}{c}\text { Kegiatan } \\
\text { yang } \\
\text { dilakukan }\end{array}$ \\
\hline & $\begin{array}{l}\text { Senin } \\
03 / 12 \\
118\end{array}$ & $\begin{array}{l}07: 00- \\
16: 00\end{array}$ & $\begin{array}{l}\text { Kantor } \\
\text { Desain }\end{array}$ & $\begin{array}{l}\text { Memantau } \\
\text { proses } \\
\text { perancanga } \\
\text { n desain } \\
\text { yang sudah } \\
\text { berlangsun } \\
\text { g dari dulu. }\end{array}$ \\
\hline 2 & $\begin{array}{l}\text { Selasa } \\
04 / 12 \\
\end{array}$ & $\begin{array}{l}07: 00- \\
16: 00\end{array}$ & $\begin{array}{l}\text { Kantor } \\
\text { Desain }\end{array}$ & $\begin{array}{l}\text { Proses } \\
\text { pembuatan } \\
\text { produk rak } \\
\text { sepatu }\end{array}$ \\
\hline
\end{tabular}




\begin{tabular}{|c|c|c|c|c|}
\hline 3 & $\begin{array}{l}\text { Rabu } \\
05 / 12 \\
/ 18\end{array}$ & $\begin{array}{l}07: 00- \\
16: 00\end{array}$ & $\begin{array}{l}\text { Kantor } \\
\text { Desain }\end{array}$ & $\begin{array}{l}\text { Mencari } \\
\text { data mesin } \\
\text { molding } \\
\text { injection, } \\
\text { mencari } \\
\text { katalog } \\
\text { molding } \\
\text { plastic }\end{array}$ \\
\hline 4 & $\begin{array}{l}\text { Kamis } \\
06 / 12 \\
/ 18\end{array}$ & $\begin{array}{l}07: 00- \\
16: 00\end{array}$ & $\begin{array}{l}\text { Bengke } \\
\text { l }\end{array}$ & $\begin{array}{l}\text { Melihat } \\
\text { stok } \\
\text { material } \\
\text { yang ada, } \\
\text { mencari } \\
\text { molding } \\
\text { lama yang } \\
\text { sudah tidak } \\
\text { dipakai } \\
\text { untuk } \\
\text { diambil } \\
\text { komponen } \\
\text { yang masih } \\
\text { bisa } \\
\text { digunakan. }\end{array}$ \\
\hline 5 & $\begin{array}{l}\text { Jumat } \\
07 / 12 \\
/ 18\end{array}$ & $\begin{array}{l}07: 00- \\
16: 00\end{array}$ & $\begin{array}{l}\text { Kantor } \\
\text { Desain }\end{array}$ & $\begin{array}{l}\text { Proses } \\
\text { pembuatan } \\
\text { molding rak } \\
\text { sepatu. }\end{array}$ \\
\hline 6 & $\begin{array}{l}\text { Sabtu } \\
08 / 12 \\
/ 18\end{array}$ & $\begin{array}{l}07: 00- \\
15: 00\end{array}$ & $\begin{array}{l}\text { Kantor } \\
\text { Desain }\end{array}$ & $\begin{array}{l}\text { Proses } \\
\text { menganalisi } \\
\text { s molding } \\
\text { rak sepatu. }\end{array}$ \\
\hline
\end{tabular}

\section{HASIL DAN PEMBAHASAN}

\section{Molding Rak Sepatu}

Pada proses Analisis ini, Analisis yang digunakan adalah stress analysis pada software autodesk invertor profsioanal 2017. Analisis ini bertujuan untuk mengetahui tegangan pada plate insert cavity dengan material baja Stainless Steel yang digunakan pada molding rak sepatu.

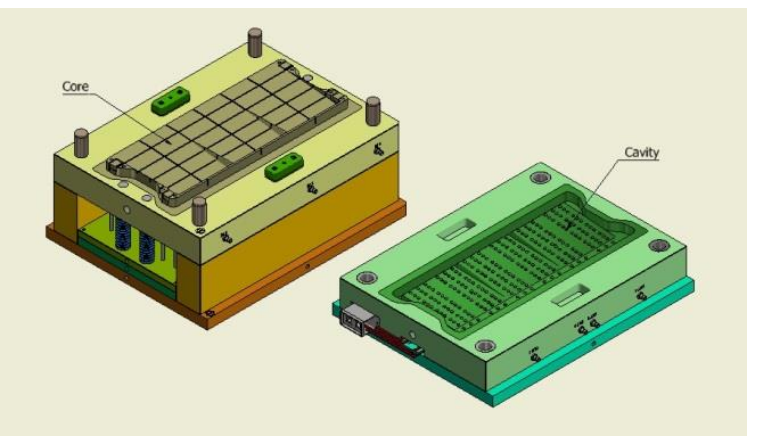

Gambar 2 Molding Rak Sepatu

Pada gambar molding rak sepatu akan diambil plate insert cavity untuk dianalisis, diambil plate insert cavity karena bagian tersebut terkena langsung dari bahan yang akan dicetak sehingga harus bahan harus kuat dan dibagian tersebut juga terkena tekanan dari nozzle mesin injection plastik, setelah selesai dianalisis maka akan diperoleh data seperti : von misess, stress, displacement, stran dan safety factor. Dengan hasil tersebut bisa diketahui apakah desain layak untuk dibuat atau perlu direvisi lagi.

\section{Analisis Tegangan}

Untuk mengetahui kekuatan desain, dilakukan analisis tegangan. Tegangan yang dianalisis merupakan tegangan yang dihasilkan dari pembebanan statis. dan hasil dari analisis tegangan yang dilakukan adalah sebagai berikut:

\section{Pemberian Beban}

Dalam analisis tegangan, salah satu hal yang penting adalah memberikan beban kepada desain. Beban yang diberikan adalah dalam bentuk tekanan dengan satuan Mpa. Karena desain diperuntukkan untuk Mesin injection yang bertekanan total $160 \mathrm{Mpa}$, beban simulasi yang diberikan kepada desain setidaknya adalah $80 \mathrm{Mpa}$ pada setiap point karana dalam satu part ada 2 point yang diberi tekanan yang sama, Lokasi pemberian beban dapat dilihat dengan lebih jelas pada Gambar 4.2.

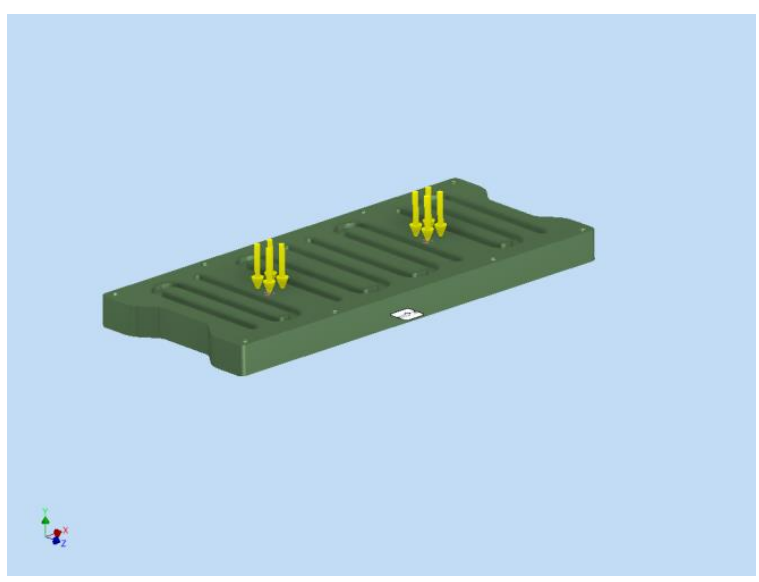

Gambar 3 Tampilan Posisi Presure

Tabel 2 Pressure hasil report autodesk inventor profesional 2017 


\begin{tabular}{|l|c|}
\hline Load Type & Pressure \\
\hline Magnitude & $160 \mathrm{a}$ \\
\hline
\end{tabular}

\section{Spesifikasi Material Pada Desain Plat} insert cavity

Dalam pembuatan molding sangat penting untuk menentukan suatu material untuk menunjng kuwalitas hasil product, salah satu material yang harus diperhatikan yaitu material yang bersentuhan langsung dengan product karena material tersebut harus bagus dan tahan panas, tidak lengket dengan product, tidak korosi, maka untuk pembuatan plat insert cavity menggunakan material Stainless Steel yang cocok untuk digunakan. Pada desain plate insert cavity didapat hasil physical seperti Mass sebesar $68,69 \mathrm{~kg}$, luas area $842.961 \mathrm{~mm}^{2}$, dan volume sebanyak $8.586 .380 \mathrm{~mm}^{3}$

Tabel 3 Physical hasil report autodesk inventor profesional 2017

\begin{tabular}{|l|ll|}
\hline Material & Stainless Steel \\
\hline Density & $8 \mathrm{~g} / \mathrm{cm}^{\wedge} 3$ \\
\hline Mass & $68,691 \mathrm{~kg}$ \\
\hline Area & $842961 \mathrm{~mm}^{\wedge} 2$ & \\
\hline Volume & $8586380 \mathrm{~mm}^{\wedge} 3$ & $\mathrm{~mm}$ \\
\hline $\begin{array}{l}\text { Center } \\
\text { Gravity }\end{array}$ & $\begin{array}{l}\mathrm{x}=-0,304893 \\
\mathrm{y}=35,0057 \\
\mathrm{z}=10,2618 \mathrm{~mm}\end{array}$ \\
\hline
\end{tabular}

\section{Spesifikasi Material Stainless Steel}

Hasil dari analisi juga menampilkan kekuatan dari material Stainless Steel itu sendiri dengan begitu kita dapat melihat kekuatan maksimum dari suatu material.

\section{Tabel 4 Material Stainless Steel}

\begin{tabular}{|c|c|c|}
\hline Name & \multicolumn{2}{|l|}{ Stainless Steel } \\
\hline \multirow{3}{*}{ General } & Mass Density & $\begin{array}{l}8 \\
\mathrm{~g} / \mathrm{cm}^{\wedge} 3\end{array}$ \\
\hline & Yield Strength & $\begin{array}{l}250 \\
\mathrm{MPa}\end{array}$ \\
\hline & $\begin{array}{l}\text { Ultimate Tensile } \\
\text { Strength }\end{array}$ & $\begin{array}{l}540 \\
\mathrm{MPa}\end{array}$ \\
\hline \multirow[t]{2}{*}{ Stress } & Young's Modulus & $\begin{array}{l}193 \\
\text { GPa }\end{array}$ \\
\hline & Poisson's Ratio & $0,3 \mathrm{ul}$ \\
\hline
\end{tabular}

\begin{tabular}{|l|l|l|}
\hline & Shear Modulus & $\begin{array}{l}74,2308 \\
\mathrm{GPa}\end{array}$ \\
\hline Part Name(s) & Insert Cavity \\
\hline
\end{tabular}

\section{Hasil Analisis Keseluruhan dari Software Autodesk Inventor Professional 2017}

Setelah menginput data analisis software dapat diperoleh hasil tegangan minimum sampai ke maximum yang meliputi Von Mises, Stress, Displacement, Strain, Safety Factor dari hasil tersebut dapat ditarik kesimpulan mengenai keamanan suatu desain dengan begitu ketika bahan dibuat tidak akan ada kegagalan.

Tabel 5 Hasil Report Analisis Menggunakan Autodesk Inventor Professional

\begin{tabular}{|c|c|c|}
\hline Name & Minimum & Maximum \\
\hline Volume & \multicolumn{2}{|l|}{$8586380 \mathrm{~mm}^{\wedge} 3$} \\
\hline Mass & \multicolumn{2}{|l|}{$68,691 \mathrm{~kg}$} \\
\hline $\begin{array}{ll}\text { Von } & \text { Mises } \\
\text { Stress } & \end{array}$ & $\begin{array}{l}0,0234753 \\
\text { Мра }\end{array}$ & $124,201 \mathrm{MPa}$ \\
\hline $\begin{array}{l}\text { 1st Principal } \\
\text { Stress }\end{array}$ & $-70,6359 \mathrm{MPa}$ & $118,063 \mathrm{MPa}$ \\
\hline $\begin{array}{l}\text { 3rd Principal } \\
\text { Stress }\end{array}$ & $-163,596 \mathrm{MPa}$ & $21,3866 \mathrm{MPa}$ \\
\hline Displacement & $0 \mathrm{~mm}$ & $0.065786 \mathrm{~mm}$ \\
\hline Safety Factor & $2,01286 \mathrm{ul}$ & $15 \mathrm{ul}$ \\
\hline Stress XX & $-138,616 \mathrm{MPa}$ & $102,777 \mathrm{MPa}$ \\
\hline Stress XY & $-28,7152 \mathrm{MPa}$ & $29,3344 \mathrm{MPa}$ \\
\hline Stress XZ & $-70,9972 \mathrm{MPa}$ & $66,1018 \mathrm{MPa}$ \\
\hline Stress YY & $-100,233 \mathrm{MPa}$ & $32,0809 \mathrm{MPa}$ \\
\hline Stress YZ & $-25,326 \mathrm{MPa}$ & $27,4301 \mathrm{MPa}$ \\
\hline Stress ZZ & $-149,691 \mathrm{MPa}$ & $114,513 \mathrm{MPa}$ \\
\hline $\mathrm{X}$ Displacement & $\begin{array}{l}-0,00733737 \\
\mathrm{~mm}\end{array}$ & $0,00734769 \mathrm{~mm}$ \\
\hline Y Displacement & $-0,065786 \mathrm{~mm}$ & $0,0017212 \mathrm{~mm}$ \\
\hline Z Displacement & $\begin{array}{l}-0,00759345 \\
\mathrm{~mm}\end{array}$ & $0,00957477 \mathrm{~mm}$ \\
\hline Equivalent & 0,0000001167 & $0.000602955 \mathrm{ul}$ \\
\hline
\end{tabular}




\begin{tabular}{|l|l|l|}
\hline Strain & $94 \mathrm{ul}$ & \\
$\begin{array}{l}\text { 1st Principal } \\
\text { Strain }\end{array}$ & $\begin{array}{l}0,0000966427 \\
\mathrm{ul}\end{array}$ & $0,00061902 \mathrm{ul}$ \\
\hline $\begin{array}{l}\text { 3rd Principal } \\
\text { Strain }\end{array}$ & $\begin{array}{l}-0,000635598 \\
\mathrm{ul}\end{array}$ & $\begin{array}{l}- \\
0,000000010497 \\
8 \mathrm{ul}\end{array}$ \\
\hline Strain XX & $\begin{array}{l}-0,000585189 \\
\mathrm{ul}\end{array}$ & $0,000516402 \mathrm{ul}$ \\
\hline Strain XY & $\begin{array}{l}-0,000193419 \\
\mathrm{ul}\end{array}$ & $0,000197589 \mathrm{ul}$ \\
\hline Strain XZ & $\begin{array}{l}-0,000478219 \\
\mathrm{ul}\end{array}$ & $0,000445246 \mathrm{ul}$ \\
\hline Strain YY & $\begin{array}{l}-0,000334329 \\
\mathrm{ul}\end{array}$ & $0,000152352 \mathrm{ul}$ \\
\hline Strain YZ & $\begin{array}{l}-0,00017059 \\
\mathrm{ul}\end{array}$ & $0,000184762 \mathrm{ul}$ \\
\hline Strain ZZ & $\begin{array}{l}-0,000613764 \\
\mathrm{ul}\end{array}$ & $0,000585602 \mathrm{ul}$ \\
\hline
\end{tabular}

\section{Von Mises Stress}

Von mises stress adalah tegangan yang nilainya didapat dari teori kegagalan karena energi distorsi. Jika nilai von mises stress melebihi tegangan luluh dari material, maka desain akan mengalami kegagalan. Pada simulasi tegangan, dari hasil analisis von misses tersebut dapat diketahui dengan melihat perubahan warna yg terjadi dimana warna merah menunjukkan tekanan yang terbesar sedangkan warna biru tidak menerima tekanan sama sekali, seperti yang dapat dilihat pada Gambar 4.3. Dari simulasi yang dilakukan, nilai von mises stress maksimum yang terjadi pada kondisi terbeban adalah 124,2 Mpa sedangangkan untuk nilai minimumnya $0 \mathrm{Mpa}$. Nilai tersebut hanya terjadi di beberapa titik yang umumnya muncul di area dekat titik pembebanan, dan tidak melampaui nilai tegangan luluh material Stainless Steel yang sebesar $250 \mathrm{MPa}$. Sebagian besar hasil analisis tegangan pada desain plate insert cavity masih berwarna biru. Yang Artinya Von mises stress yang terjadi masih masuk dalam batas yang aman.

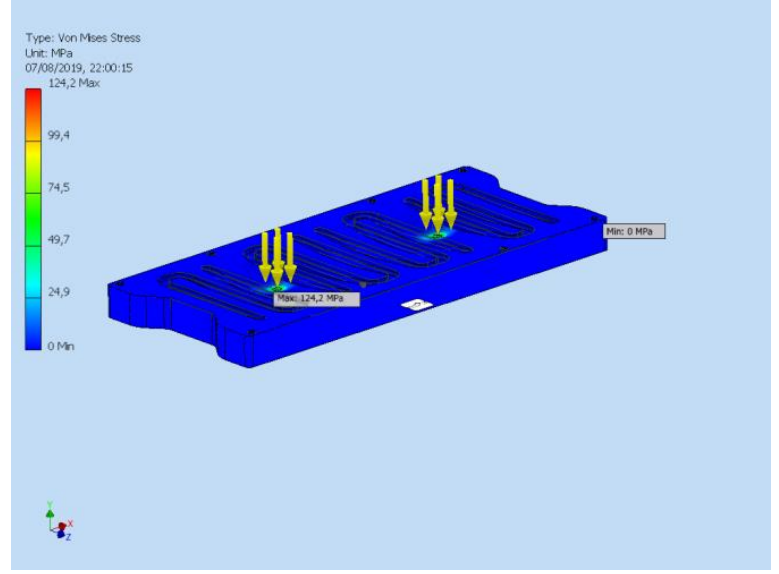

Gambar 4 Tampilan Von Mises Stress

Perhitungan manual dari von misess Stress :

Diketahui $\quad: \sigma_{1}: 118,063 \mathrm{Mpa}$

Ditanya von misess stress $\sigma^{\prime}$ ?

$$
\sigma_{3}: 21,3866 \mathrm{Mpa}
$$

Jawab :

$$
\sigma^{\prime}=\sqrt{\sigma_{1}^{2}-\sigma_{1} * \sigma_{3}+\sigma_{3}^{2}}
$$

$$
\begin{aligned}
& \sigma^{\prime}= \\
& \sqrt{118,063^{2}-118,063 * 21,3866+21,3866^{2}} \\
& \sigma^{\prime}= \\
& \sqrt{118,063^{2}-118,063 * 21,3866+21,3866^{2}} \\
& \sigma^{\prime}= \\
& \sqrt{13938.8719-2524.9661+457.3866} \\
& \sigma^{\prime}=\sqrt{11871.2925} \\
& \sigma^{\prime}=124 \mathrm{MPa}
\end{aligned}
$$

\section{Principal Stress}

stress adalah analisis yang menunjukkan luas area yang menerima beban gaya dengan pembagian luas bidang yang terkena tekanan, dari hasil analisis strees tersebut dapat diketahui dengan melihat perubahan warna yg terjadi dimana warna merah menunjukkan tekanan yang terbesar sedangkan warna biru menunjukkan tekanan yang terkecil. Dari simulasi yang dilakukan, nilai Stress maksimum yang terjadi pada kondisi terbeban adalah 118,1 Mpa sedangangkan untuk nilai minimumnya -70,6 Mpa. 


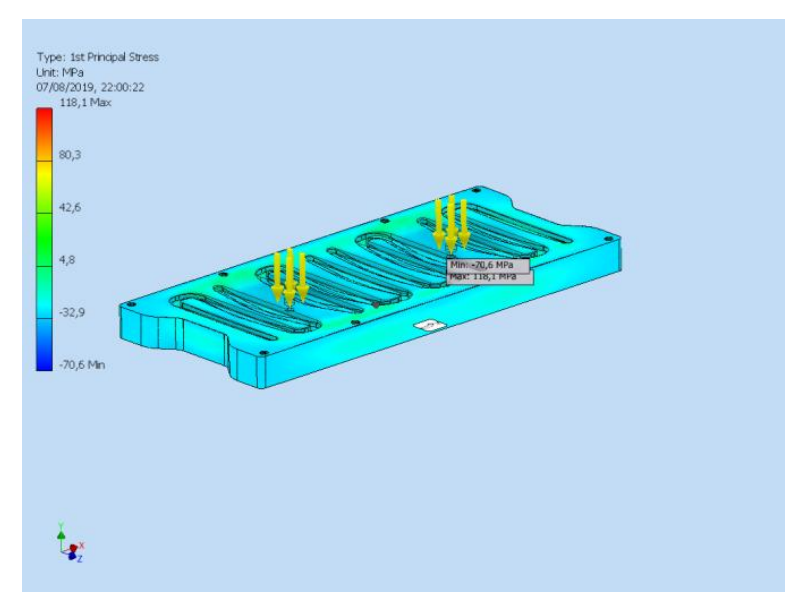

Gambar 5 Tampilan Principal Stress

Perhitungan manual dari Stress :

Diketahui : F : $57090.544 \mathrm{~N}$

A : $0.00048356 \mathrm{~m}^{2}$

Ditanya Stress $\sigma$ ?

$$
\begin{aligned}
\text { Jawab : } \sigma & =\frac{\mathrm{F}}{\mathrm{A}} \\
\sigma & =\frac{57090.544 \mathrm{~N}}{0.00048356 \mathrm{~m}^{2}} \\
\sigma & =118062999 \mathrm{~N} / \mathrm{m}^{2} \\
\sigma & =118.06 \mathrm{MPa}
\end{aligned}
$$

\section{Displacement}

Displacement menunjukkan perubahan bentuk atau suatu lendutan dari desain setelah dilakukan pembebanan. Pada simulasi tegangan, nilai dispacement yang terjadi dapat diketahui dengan melihat perubahan warna yang terjadi pada desain, Untuk warna merah menunjukkan perubahan jarak terjauh dari titik awal., seperti yang dapat dilihat pada Gambar 4.5. Dari simulasi yang dilakukan, nilai displacement maksimum yang teljadi pada kondisi terbeban adalah $0,06579 \mathrm{~mm}$ sedangangkan untuk nilai minimumnya $0 \mathrm{~mm}$. Displacement ini terjadi pada tegangan maksimal 160 Mpa, masih jauh di bawah tegangan material Stainless Steel yang sebesar $250 \mathrm{MPa}$. Artinya displacement masih berada pada daerah elastis. Dengan nilai yang cukup kecil, displacement ini masih dapat diterima.

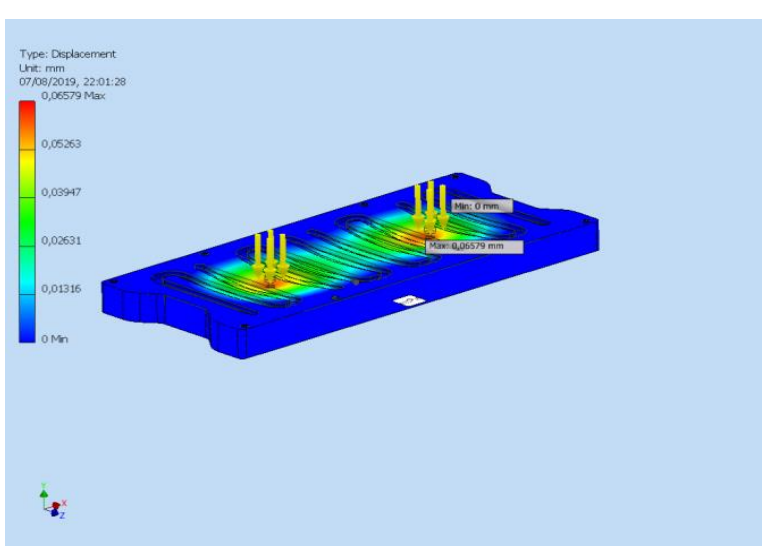

Gambar 6 Displacement
Perhitungan manual dari displacement :

Dikethui : P : $160 \mathrm{Mpa}$

$$
\begin{aligned}
& \text { a : } 20 \mathrm{~cm} \\
& E: 193 \mathrm{Gpa} \\
& \mathrm{L}: 76 \mathrm{~cm} \\
& \text { I }: 82.583 \mathrm{Kg} \mathrm{m}^{2}
\end{aligned}
$$

Ditanya displacementy?

$$
\begin{aligned}
\text { Jawab } \quad: \quad y=\frac{p a}{24 E I}\left(3 L^{2}-4 a^{2}\right) \\
y=\frac{80 \cdot 20}{24 \cdot 193 \cdot 82583}\left(3 \cdot 76^{2}-4 \cdot 20^{2}\right) \\
y=\frac{10 \cdot 20}{3 \cdot 193 \cdot 82583}\left(3 \cdot 19^{2}-4 \cdot 5^{2}\right) 4^{2} \\
y=\frac{200}{47815557}(3 \cdot 361-4 \cdot 25) 16 \\
y=\frac{200}{47815557} \cdot 983 \cdot 16 \\
y=\frac{3145600}{47815557} \\
y=0,0657861 \mathrm{~mm}
\end{aligned}
$$

\section{Equivalent Strain}

Strain adalah dinyatakan sebagai pertambahan panjang per satuan panjang. Tegangan pada suatu titik dihitung setelah regangan diukur.perubahan warna yg terjadi dimana warna merah menunjukkan area terluas yang menerima pertambahan panjang . sedangkan warna biru tidak menunjukkan perubahan panjang. seperti yang dapat dilihat pada Gambar 4.6. Dari simulasi yang dilakukan, nilai strain maksimum yang teljadi pada kondisi terbeban adalah 6,03 $\mathrm{x}$ $10^{-4}$ sedangangkan untuk nilai minimumnya 1,168 x $10^{-7}$, Regangan yang terjadi pada tegangan 160 $\mathrm{MPa}$

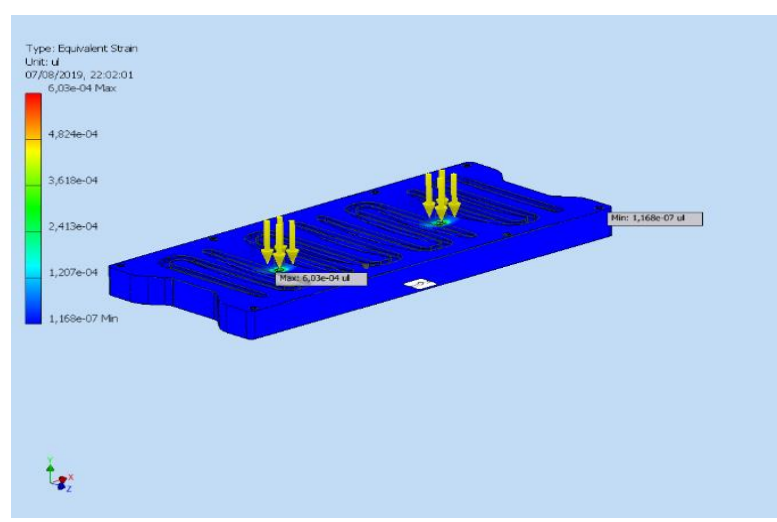

Gambar 7 : Strain

Perhitungan manual dari Strain : 
Diketahui : $\delta: 0.000065786 \mathrm{~m}^{2}$

$$
\mathrm{L}: 0.109105986 \mathrm{~m}^{2}
$$

Ditanya Regangan $\in$ ?

$$
\begin{aligned}
\text { Jawab } \in & =\frac{\delta}{L} \\
\epsilon & =\frac{0.000065786 \mathrm{~m}^{2}}{0.109105986 \mathrm{~m}^{2}} \\
\epsilon & =0.000602955
\end{aligned}
$$

\section{Faktor Keamanan ( Safety Factor)}

Safety factor adalah faktor yang digunakan utk mengevaluasi keamanan dari suatu desain.Dimana kisaran faktor dari 1 sampai 15 faktor keamanan yang baik harus lebih dari 1 utk menghindari terjadinya kegagalan suatu desain.Warna biru menunjukkan desain paling aman.Dan warna merah menunjukkan desain di luar batas aman. Untuk Safety factor atau faktor keamanan yang didapat dari hasil analisis adalah sebesar 2,01 sampai 15. Artinya, bagian paling lemah pada desain mampu mengatasi 2,01 kali beban yang diijinkan. Walaupun begitu, seperti yang dapat dilihat pada Gambar 4.7, mayoritas bagian plate insert cavity berwama biru. Artinya sebagian besar memiliki safety factor di atas beban yang diijinkan.

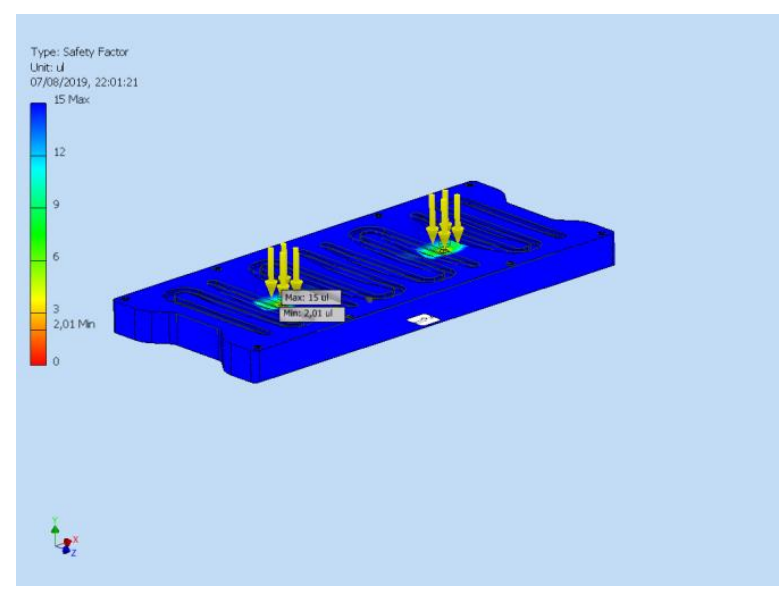

Gambar 8 Safety Factor

Perhitungan manual dari safety factor :

Diketahui $\quad: \mathrm{S}_{\mathrm{y}}: 250 \mathrm{Mpa}$

Ditanya : $\mathrm{n}$ ?

$$
\sigma_{\mathrm{e}}: 124,2 \mathrm{Mpa}
$$

Jawab : $\quad n=\frac{s_{y}}{\sigma_{e}}$

$$
\begin{aligned}
& n=\frac{250 \mathrm{MPa}}{124,2 \mathrm{MPa}} \\
& n=2,01
\end{aligned}
$$

\section{Kesimpulan}

Dari hasil analisis pada plate insert cavity rak sepatu yang telah dilakukan pembebanan menggunakan bantuan software autodesk inventor 2017, dapat disimpulkan bahwa:

1. Setelah melakukan analisis desain plate insert cavity pada tekanan 160 Mpa diperoleh data tegangan von mises sebesar124,2 Mpa yang masih pada batas aman, Principal Stress sebesar 118,1 Mpa, Displacement sepanjang 0,06579 mm dan Strain sebesar adalah 6,03 x $10^{-4}$

2. Berdasarkan analisis desain yang telah dilakukan, Diperoleh nilai sefety factor Terendah adalah 2,01, nilai tersebut merupakan nilai terendah dari desain yang di analisis, rata-rata bagian plate insert cavity berwama biru. Artinya sebagian besar memiliki safety factor di atas beban yang diijinkan. Dapat disimpulkan bahwa desain aman untuk dibuat secara real.

\section{Saran}

Adapun saran-saran yang dapat diberikan sebagai acuan dalam penelitian selanjutnya adalah sebagai berikut:

1. Untuk flow pendingin molding di analisis supaya molding tidak cepat panas sehingga product yang dihasilkan lebih bagus.

2. Perlu pengoptimalan mesin Injection dengan cara simulation flow bahan pada molding yang sudah dibuat.

3. Perlu adanya perhitungan material dan pengerjaan secara menyeluruh dari pembuatan molding awal hingga molding jadi.

\section{DAFTAR PUSTAKA}

Afifah, Y. N. (2019). Analysis of Unsteady Magneto Hydro Dynamic ( MHD ) Nano Fluid Flow Past A Sliced Sphere Analysis of Unsteady Magneto Hydro Dynamic ( MHD ) Nano Fluid Flow Past A Sliced Sphere. https://doi.org/10.1088/1757899X/494/1/012033

Hadi Wijaya. (2010a). Konstruksi Dasar Mold 2 Pelat. Retrieved July 21, 2019, from http://injeksiplastik.blogspot.com/2010/02/ 2-plate-type-mold-basic-structure.html

Hadi Wijaya. (2010b). Konstruksi Dasar Mold 3 Pelat. Retrieved July 21, 2019, from http://injeksiplastik.blogspot.com/2010/02/ 3-plate-type-mold-basic-structure.html

Kursus cad. (2015). Pengenalan Inventor. Retrieved from http://www.kursuscad.net/2015/04/pengen alan-inventor.html?m=1

Lasinta Ari Nendra Wibawa. (2018). Simulasi Kekuatan Komponen Sarana Pengujian Roket Menggunakan Autodesk Inventor Professional 2017 (Kinanthi Anggraini, Ed.). Buku Katta. 
Lutfi Khoirul Miftakhul Ni'am. (2016). Desain Dan Optimasi Injection Mold Sistem Slider Pada Produk Preform Stick T15. IOSR Journal of Economics and Finance, 3(1), 56. https://doi.org/https://doi.org/10.3929/eth z-b-000238666

Majanasastra, R. B. S. (2013). Analisis defleksi dan tegangan shock absorber roda belakang sepeda motor yamaha jupiter 1).1(1), 1-7.

PT. Reasuransi Indonesia Utama ( Persero ). (2017). Proses Produksi Dan Risiko Pabrik Plastik (Injection Molding). Retrieved July 21, 2019, from www.indonesiare.co.id

Robert L. Mott, P. . (2009). Elemen - Elemen Mesin Dalam PerancanganMekanis (Bahasa Ind; D. Prabantini, Ed.). Yogyakarta.

Setyono, B. (2016). Perancangan Dan Analisis Kekuatan Frame Sepeda Hibrid "Trisona" Menggunakan Software Autodesk Inventor. Jurnal IPTEK, 20(2), 37. https://doi.org/10.31284/j.iptek.2016.v20i2. 43

Yulianto, I., \& Prassetiyo, H. (2014). Rancangan Desain Mold Produk Knob Regulator Kompor Gas Pada Proses Injection Molding *. Jurnal Online Institut Teknologi Nasional, Vol. 02, pp. 140-151. 
MI Ulumuddin / Mechonversio, Vol. 2, No.2, Desember 2019, 1-10

Halaman ini sengaja dikosongkan 